DOI: $10.17569 /$ tojqi. 453426

Research Article

\title{
Development of Argumentation Skills through Socioscientific Issues in Science Course: A Collaborative Action Research ${ }^{1}$
}

\author{
Ayşe Öztürk ${ }^{2}$, Ahmet Doğanay ${ }^{3}$
}

\begin{abstract}
This study was designed as a collaborative action research, aimed to develop secondary school 8th graders' argumentation skills through socioscientific issues (SSI) in science course. The participants of the research were comprised of 26 eight graders. In the study, an action plan which had lasted 27 weeks was implemented. The data was collected by means of written documents related to the argumentation skills, unstructured observations, teacher and student diaries. The data was analyzed using content analysis. The study results showed that at the end of the implementation, all students were able to create arguments that were comprised of components of claim, warrant, evidence, counter claim-warrantand rebuttal. Also, in the process of development of argumentation skills, some problems both related to the components of argumentation skills and learning-teaching variables were observed. Thisresearch is significant in terms of presenting information regarding regulations to be made for the development of argumentation skills through SSI in science course and problems that may be encountered in this process, forimplementation processof collaborative action research.
\end{abstract}

Keywords: Qualitative research, Collaborative action research, Science education, Socioscientific issues, Argumentation skills

\footnotetext{
1 This study is based on $\mathrm{PhD}$ thesis of the first author supervising by the second author and presented at 3rd National Congress on Curriculum and instruction, Turkey

2 Asst.Prof.Dr., Gaziantep University, Faculty of Education, Department of Primary Education, ozturkayse2007@gmail.com, https://orcid.org/0000-0001-9279-1716

3 Prof.Dr., Çukurova University, Faculty of Education, Departman of Educational Sciences, adoganay@cu.edu.tr, https://orcid.org/0000-0002-8482-225X
}

Received: 14.08.2018 Accepted: 30.01.2019 


\title{
Fen Bilimleri Dersinde Sosyobilimsel Konularla Argümantasyon Becerisi Geliştirilmesi: Bir İşbirlikçi Eylem Araştırması
}

\begin{abstract}
$\ddot{O} z$
Sosyobilimsel konularla fen bilimleri derslerinde ortaokul sekizinci sınıf öğrencilerinde argümantasyon becerisi geliştirilmesinin amaçlandığı bu çalışma işbirlikçi eylem araştırması olarak desenlenmiştir. Araştırmanın çalışma grubunu, 26 sekizinci sınıf öğrencisi oluşturmuştur. Araştırmada, 27 hafta uygulama gerçekleştirilmiştir. Veriler argümantasyon becerisine ilişkin yazılı dokümanlar, yapılandırılmamış gözlem, öğretmen ve öğrenci günlükleri ile toplanmıştır. Araştırma verileri içerik analizi yapılarak çözümlenmiştir. Araştırma sonuçları, uygulama sonunda öğrencilerin tamamının iddia, gerekçe, kanıt, karşı iddia ve gerekçe ile çürütücü bileşenlerinden oluşan argümanlar üretebildiklerini göstermiştir. Ayrıca, argümantasyon becerisi gelişimi sürecinde argümantasyon becerisi bileşenleriyle ve öğretme-öğrenme süreci değişkenleriyle ilgili çeşitli problemler saptanmıştır. Araştırma, sosyobilimsel konularla argümantasyon becerisi gelişimi için yapılacak düzenlemeler ve süreçte karşılaşılabilecek problemlerle ilgili bilgiler sunması, işbirlikçi eylem araştırmasının uygulama süreci hakkında bilgi vermesi açısından önem taşımaktadır.
\end{abstract}

Anahtar Sözcükler: Nitel araştırma, İşbirlikçi eylem araştırması, Fen eğitimi, Sosyobilimsel konular, Argümantasyon becerisi 


\section{Introduction}

Science education studies have shown a significant interest in argumentation in the last decade, and argumentation has become a common goal for science education curriculums in many countries (Özdem Yilmaz, Cakiroglu, Ertepinar, \& Erduran, 2017). Argumentation has been defined as a process of asserting, supporting, criticising and purifying an idea/a perspective (Osborne, Collins, Ratcliffe, Miller, \& Duschl, 2003). The main aim of argumentation in science education is to develop students' skills to produce evidence to support their perspectives (Sandoval \& Millwood, 2008; Yore, Florence, Pearson, \& Weaver, 2006). In addition to this, argumentation is identified as a central point for scientific implementations in science classes (Newton, Driver, \& Osborne, 1999). Developing students' communication and critical thinking skills, supporting their science literacy development, and cultivating skills of reasoning and the ability to select opinions and theories based on logical criteria are considered among the contributions that argumentation can bring to science classes (Jimenez-Aleixandre \& Erduran, 2007). Furthermore, argumentation has numerous functions in science classes, such as ensuring understanding of the epistemology of scientific knowledge, identifying the effects of personal and social values on decision making, and allowing the evaluation of evidence from multiple perspectives (Driver, Newton, \& Osborne, 2000). The fact that argumentation has made significant contributions to the process of science education makes studies on equipping pupils with this skill crucial. In that regard, there seems to be a large number of studies on the development of argumentation skills (Driver et.al, 2000; Erduran, Ardac, \& Yakmac1-Güzel, 2006; Kuhn, 2010; Lazarou, Sutherland, \& Erduran, 2016; Osborne, Erduran, \& Simon, 2004; Özdem Yilmaz et al., 2017; Sadler \& Donnelly, 2006; Simon, Erduran, \& Osborne, 2006; Yan \& Erduran, 2008; Yerrick, 2000). It appears that the analysis of factors which are influential in the development of argumentation skills, the assessment of levels of argumentation skills, and experimental studies on developing argumentation skills have an important place among these studies. One of the contexts in which argumentation skills can be cultivated during science education appears to be the integration of SSI. SSI reflect social dilemmas and debates that emerge in relation to scientific and technological products and processes, and harbor ethical and moral meanings at their center (Sadler \& Zeidler, 2005a). SSI, constituting an important part of science literacy (AAAS, 1990; Fensham, 2002; Roberts, 2007; Sadler, 2004), spark debates 
that create an opportunity to generate different opinions and argumentation (Simonneaux, 2007).

Accordingly, it is observed that various studies (Akbaş \& Çetin, 2018; Atabey \& Topçu, 2017; Dawson \& Venville, 2010; Dawson \& Carson, 2017; Evren-Yapıcığlu \& Kaptan, 2018; Lin \& Mintzes, 2010; Martín-Gámez \& Erduran, 2018; Molinatti, Girault, \& Hammond, 2010; Öztürk, 2017; Ritchie, Tomas, \& Tones, 2011; Romero, 2018; Sadler \& Donnelly, 2006; Zeidler \& Nichols, 2009; Zohar \& Nemet, 2002; Tsai, 2017) within the related literature have been conducted on argumentation skills developed through SSI. Among these studies, it can be seen that research related to socioscientific issues are also plentiful. For example; Lin and Mintez (2010), in their study with sixth graders, aimed to improve argumentation skills in socioscientific topics through individualized teaching practices. Dawson and Venville (2010) worked on teaching strategies to develop argumentation skills in socioscientific topics in high school genetics classes. The results of these studies show that socioscientific subjects are one of the factors to develop argumentation skills. In their experimental study, Molinatti et al. (2010) carried out a study to investigate the effects of discussions related to stem cell uses on high school students' argumentation and decision making skills. Ritchie et al. (2011) worked on the influences of academic writing project about socioscientific topics on students' science literacy development. The results showed that practice on argumentation writing on socioscientific topics supported the development of students' biology related concepts and their positive attitude towards science. Sadler et al. (2004) investigated how the students conceptualized and interpretated the nature of the science and how they evaluated the evidences about socioscientific situations. The findings indicated that interpreting the data on the nature of science in terms of making comments and evaluating socioscientific situations was affected by some factors such as scientific knowledge and personal beliefs. Zeidler and Nichols (2009) analysed various studies in their work called "Socioscientific issues: theory and practice" and explained socioscientific issues and its background. In line with this, they analysed deeply socioscientific topics and especially from the discussion perspective, sociomoral discussion, argumentation, critical thinking and discussion in detail. Osborne et al., (2004) concentrated on teaching argumentation, designing and evaluating learning environment reinforcing learning in their academic contexts. Öztürk (2017) investigated the effect of metacognition on socioscientific argumentation skills through causal-comparative 
research. Evren-Yapıcıoğlu and Kaptan (2018) in their study, aimed to investigate the effect of socioscientific issues based instruction approach on development of argumentation skills of science teacher candidates. Topçu, Sadler, \& Yilmaz-Tuzun (2010) were developed scale to evaluate argumentation skills regarding socioscientific issues. Dawson and Carson (2017), developed and tried scenarios regarding socioscientific issue of climate change to evaluate students' argumentation skills. In his research Romero (2018) aimed to determine the mental models about a social-scientific problematic specific to high-school Colombian students and to analysis the argumentative schemes regarding these mental models. Martín-Gámez and Erduran (2018) indicated in their study, how pre-service teachers view quality of arguments and teaching strategies regarding argumentation on energy which is a socio-scientific issue. Tsai (2017) in his study suggested the SSIs-Online-Argumentation Pattern (SOAP) to improve a pedagogical strategy enabling students to participate in online argumentation of SSIs. Akbaş and Çetin (2018) investigated the level of argumentation and informal reasoning of gifted students by means of the scenarios regarding socioscientific issues with a case study. Topçu \& Atabey (2017) investigated the affect of socioscientific issues based instruction on middle school students' argumentation quality. It is seen that an important part of these studies concentrated on developing argumentation skills by conducting activities based on SSI. However, in some studies (Candan, 2006; Güven, 2002; Kıvanç, 2003; Newton et al., 1999; Sandoval \& Millwood, 2005; Wu \& Tsai, 2007; Yiğittir, 2003) several problems were experienced during the development process of argumentation skills, and this skill was not sufficiently attained. For the effective development of argumentation skills, this situation requires the problems encountered during the implementation process to be determined and resolved. This calls for action research studies to be conducted.

By conducting a collaborative action research for the purpose of developing argumentation skills insecondary school students, information will be provided regarding the regulations to be established in order to cultivate these skills in science courses during secondary school years, and problems that may be encountered in this process can be identified. Considering the controversial nature of SSI, it can be said that it is an appropriate context for the development of argumentation skills during science learning-teaching process. The results from such a study will contribute to the literature working to develop argumentation skills internationally in science education, as well as studies on SSI. In line with the stated reasons, this study aimed to find the answers to the following research questions: 
How can argumentation skills be developed using SSI in science courses for 8th graders? What can problems be encountered during the implementation process? How can these problems be resolved?

\section{Method}

\section{Research Model}

This study, investigating how 8th graders' argumentation skills can be developed in science courses through SSI, is a collaborative action research. Action research is a process of inquiry about problems and taking action to solve them (Pine, 2009, p.30). It refers to teacherconducted classroom research that aims to clarify and resolve practical teaching issues and problems (Richards \& Farrel, 2005, p.171).By looking at examples of the use of the method in the research literature, we may identify features: action research is situational-it is concerned with diagnosing a problem in a specific context and attempting to solve it in that context; it is usually collaborative-teams of researchers and practitioners work together on a project; it is participatory-team members themselves take part directly or indirectly in implementing the research (Cohen \& Manion, 1994, p.186). As a collaborative process, action research begins when educational researchers, university faculty, and teachers assist each other in developing the skills to identify and conceptualize problems (Pine, 1981). In this type of research, there is collaboration between university professors who are considered as helpers of the process and school teachers where the actual research takes place (Vula \& Saqipi, 2015). Most collaborative action research focuses on practical problems defined by the participating practitioners (Elliott, 1977; Rapoport, 1970; Wallat, Green, Conlin, \& Haramis, 1981, cited by Smulyan, 1983). As Calhoun (1993) states, collaborative action research can be applied to problems occurring in a single classroom or several classrooms. In this process, teachers and researchers work together to solve problems. This research process is based on a system of discussion, investigation, and analysis in which the researchers are a part of the process (Pine, 1981). Accordingly, this study included a group of students who had experienced a problem regarding argumentation skills. The teacher and the researchers worked together in order to resolve this problem. Through this work, an action plan was developed and implemented in order to develop argumentation skills. 


\section{The Participants of the Research}

The participants of the study comprised of a total of 26 8th graders, 14 girls and 12 boys, who had experienced problems in argumentation skills. The students attended a secondary school in the city center and their academic achievement scores for science course ranged from 39.90 to 99.50 . The teacher, called as the practising teacher had seven years of teaching experience, and had observed problems in students regarding argumentation skills. She joined the study voluntarily. The school had a computer lab where students can carry out research.

\section{Procedure Conducted During the Research}

\section{Assessment studies}

The work on the identification of the situation was followed in two phases to obtain deep information about the situation. In the first, the students' argumentation skills were observed and analyzed for approximately three months. As a result of this analysis, it was seen that the students could not justify their answers through warrants and evidences. When they provided warrants, they could not use high level argumentation skills such as producing counter claimcounter warrant and rebuttal. In the second phase, the students' argumentation skills were analysed in a written way in order to identify the situation better. Two of the students were at the level of claim and warrant and the others were only at the level of claims proposing

\section{Forming the group of experts}

In accordance with the science education, argumentation skills, curriculum development, qualitative research, SSI, and the content of the SSI, a team of 14 experts from various fields was formed for the study to get their opinion on activity planning and validity studies as part of the research.

\section{Forming the validation committee}

A validation committee was formed for the study in order to consult with the experts on data analyses throughout the research practices. The validation committee included a science teacher, an expert in argumentation skills, and a person from the expert group depending on 
the subject. In the process of forming the committee, the fundamental criteria taken was that the science teacher and the argumentation skills expert should have knowledge in SSI and qualitative research. The validation committee made sure that the researchers were given the opportunity to constantly and critically question and monitor themselves, as well as the process, and that their comments regarding the occurrences or facts they thought they had observed reflected reality.

\section{Preparation and implementation of the action plan}

The action plan was prepared in consideration of the assessment study, findings from the literature review, and opinions of the group of experts. Accordingly, Toulmin's Argument Pattern (TAP) was taken as basis for the argumentation skill as is the case in majority of science education studies. TAP (1958) is being used as an important tool in studies carried out for improving argumentation knowledge during studies on science education. Moreover, it has been observed that the model has been used with various revisions due to problems regarding the understanding of the components of the model during application. In this regard, difficulties in distinguishing the components of "data and warrant" or "data and backing" is among the most important problems in application (Johnson, 1996; Zohar \& Dori, 2003; Lin \& Mintzes, 2010; Kelly, Druker, \& Chen, 1998; Sadler \& Donnelly, 2006). This model has been used in the study also after certain revisions in accordance with the related literature findings and the needs of the study. The focus during the study for developing argumentation skill was on skills of developing claim, warrant, evidence, counter claim-warrant, rebuttal. Of these; claim, warrant and rebuttal have been taken directly from TAP. In addition, the evidence component which corresponds to data in traditional logic (Aldağ, 2006) was also included in the process as was the case in the studies of Kuhn (1991) and Lin and Mintzes (2010) due to the aforementioned problems. Similar to the study by Lin and Mintzes (2010), the counter-arguments component related with developing opposing views during the argumentation period were also used after being detailed by warrants as counter claims. In conclusion, three stages were determined in the study for developing argumentation skill based on assessment findings, expert opinions and theoretical results related with the literature (Figure 1). The researchers and application teacher worked together during the study. Planning, action, observation, reflection studies (Kemmis \& McTaggart, 
1988, cited by Burns, 2010) were carried out each week for this purpose and the results acquired during this process were used for planning the upcoming week.

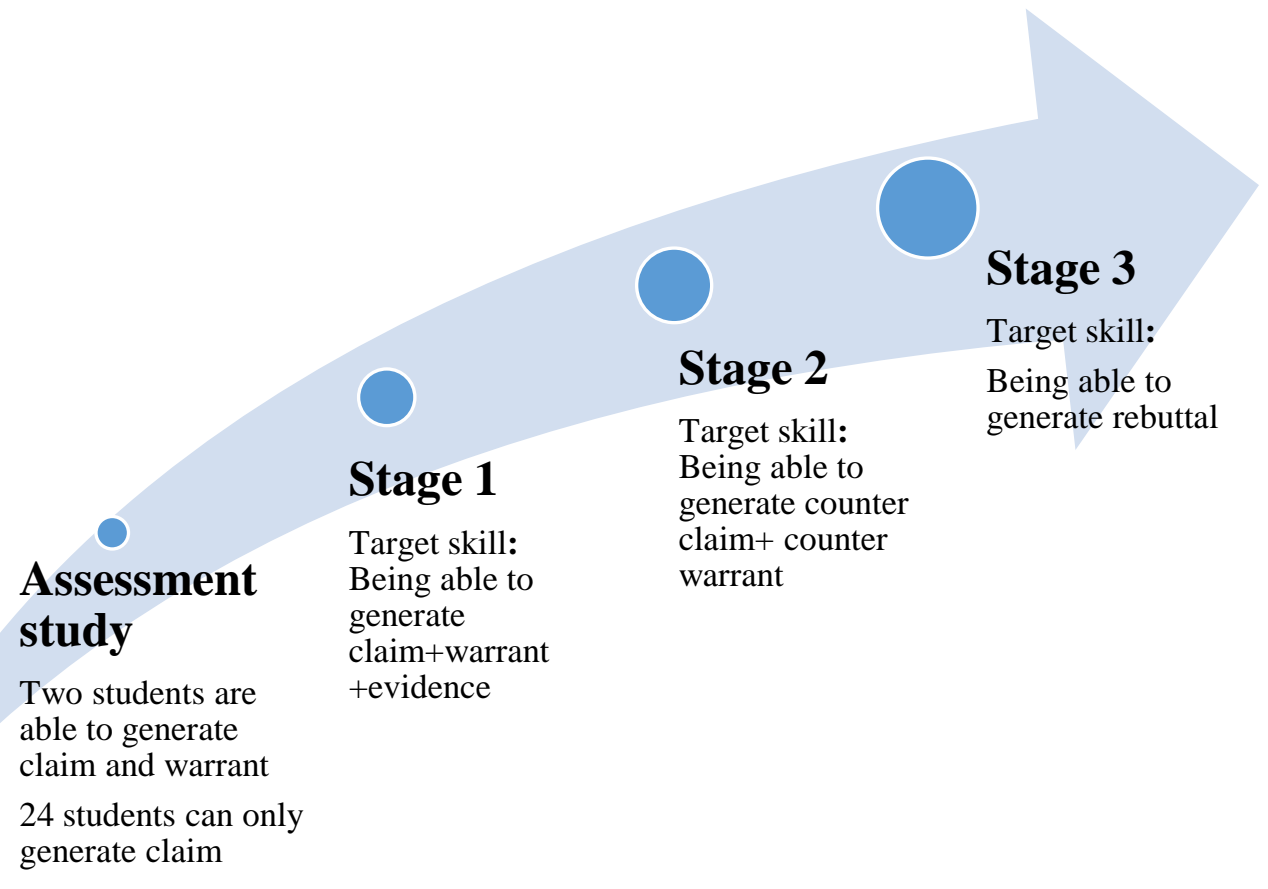

Figure 1.The research process stages of argumentation skills development

After learning outcomes were prepared for these three stages in the process of action plan development, the eighth-grade science course curriculum was examined for these outcomes with regards to SSI, and learning activities were planned. During the preparation of the activities, three dilemma scenarios were taken from the available literature (Koker, 1996, cited by Ratcliffe \& Grace, 2003; Sadler \& Zeidler, 2005a; Sürmeli, 2010). Other contradiction scenarios, media report analysis studies, and activities where legal procedures were recreated were developed by the researchers by consulting an expert opinion. The stages and activities of action plan are shown in Table 1. 
Table 1

Stages and Activities of Action Plan

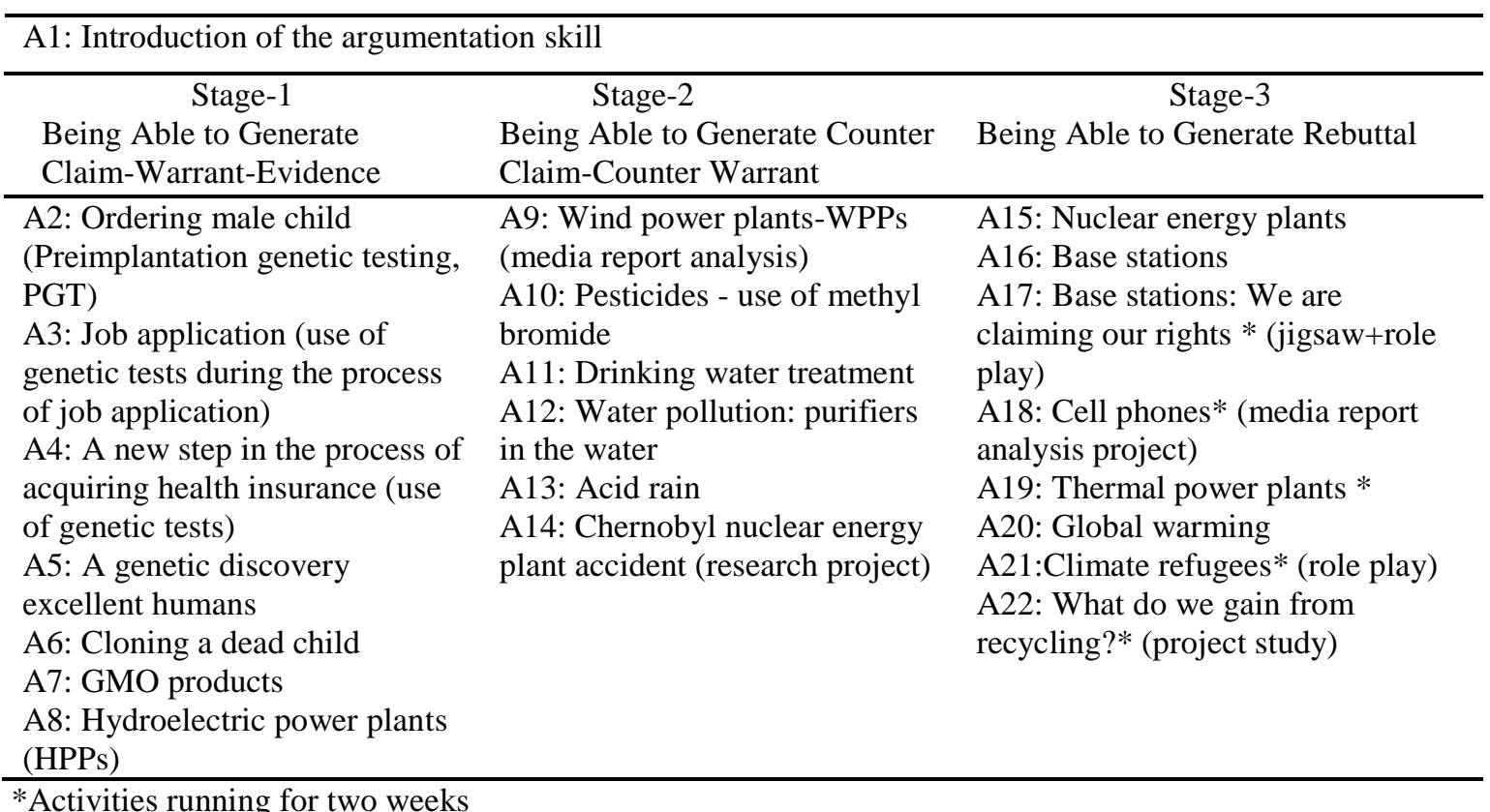

The practice period of the study, the first week as an introductory session, lasted for 27 weeks. Each week before the practice, the students were given information about which socioscientific issue was on the agenda of the activity, so they were given a chance to collect data about the issue of the activity. Additionally, supportive training was provided to pupils in order to help them become skilled in conducting research. The researcher video-recorded the process as an observer participant. During the activities, students were provided with first written and then verbal argumentation skill practices. Preparation, evaluation and problem solving-oriented practices were conducted with the teacher throughout the implementation process. Weekly qualitative data was collected from the students, analyzed for monitoring and evaluation practices and subjected to validity and credibility studies. These results provided information as to whether the desired goals were achieved, and provided a basis for the planning of the following activity to be conducted.

The procedure for a week can be summarized as follows:

In the first week, the activity entitled "ordering male child" was carried out. The aim of this activity was to develop students' ability to produce claims-warrant-evidence. In the 
preparation stage teacher and researchers worked together on the activity. In this process, the questions were answered: How will the activity be applied? What kind of questions should be asked to the students? What kind of needs should be taken into consideration? In practice process, the activity was applied by teacher and researher video recorded the process as an observer participant. During the activities, students were provided with first written and then verbal argumentation skill practices. In this process, the teacher asked the students questions requiring them to use their argumentation skills (claim-warrant-evidence). At the end of the activity, video-recordings and written documents (teacher and student diaries, activity papers) were collected and transcribed in order to determine the development of argumentation skills and to analyse the problems encountered. Also, discussions were made with the teacher about whether the objectives are achieved, what kind problems were observed by her, what kind the problems and difficulties she encountered in the application process. After collecting the data, analyses were done for both the development of argumentation skills and the problems encountered in the process. In this process, the opinion of the validity committee was also consulted and the data set was analyzed for the realibity of coding by an expert. After this process, argument structures (gaining claim-warrant-evidence generation skill, see Table 2, results for A2) and problems occured in the application process (see, pages 13-14) were determined. The teacher and researhers worked together on what to do at the next cycle and how to solve problems. In this direction, the next activity was planned. Since the desired aim was not reached in this activity, it was decided to make a new activity for the development of this aim; claim-warrant-evidence generation skill and in order to resolve problems, a meeting was planned for the students.

\section{Data Collection Tools}

\section{Pre-Assessment of Written Argumentation Skills Form (PAWASF)}

The PAWASF was used to determine the written argumentation skill levels of students in the assessment studies. PAWASF included Gene Therapy for Intelligence (Sadler \& Zeidler, 2005a), and Global Warming (Bell \& Laderman, 2003) dilemmas. In order to determine argumentation skill level, open-ended questions were prepared following the related literature (Lin \& Mintzes, 2010; Sadler \& Zeidler, 2005a; Topcu et al., 2010). PAWASF was presented to expert opinion, and it was finalized following a pilot application. 


\section{Written documents on activities and projects}

In the implementation process each week, the data regarding students' development of written argumentation skills was collected by using written documents on activity papers and projects.

\section{Unstructured observation (Video-recordings)}

The video-recordings were used for collecting data related students' verbal argumentation skills development. Furthermore, these video-recordings were presented for the examination of different researchers in order to prevent researcher bias, and they were used as data sources for validation studies. Unstructured observation was followed during all activities.

\section{Teacher and student diaries}

These diaries were used in order to see the implementation process, problems encountered, feelings and thoughts, and things that were learned from the point of view of teachers and students. In this way, data triangulation and confirming information were gained.

\section{Data Collection}

PAWASF was applied for assessment study beforestarting the implementation process. The activities were conducted for 27 weeks, and weekly video-recordings and written documents were collected throughout the process.

\section{Data Analysis}

\section{The analysis of argumentation skill development data}

In order to determine the development of argumentation skills in the study, video recordings and written document data were collected and transcribed weekly following the activities. The transcriptions were analyzed using content analysis. In the course of the analysis, the 
transcripts were read line by line multiple times, in order to determine the components of arguments generated by students. In doing so, it was aimed to see whether the students developed the target skill or not till that phase of the study. Consequently, the data collection and analysis were co-conducted at this stage, while new findings were compared with the previous ones, as well as with findings from different data sources. In short, the comparison process was consistently monitored (Glaser \& Strauss, 1967 cited by Neuman, 1991). These findings provided information on the students' development of argumentation skills during the implementation process, and were used for the planning of the following stage. Argument structure codes were grouped under three categories taking into consideration the stages from which they emerged: as argument structures regarding the claim-warrant-evidence development process, argument structures regarding the counter claim-counter warrant development process, and argument structures regarding the rebuttal development process.

\section{The analysis of the problems experienced during the argumentation skill development}

The basic principle of action researches is to detect and solve the problem encountered during the implementation process at the exact time and place it occurs (Best \& Kahn, 2006). Accordingly, analyses were conducted for the problems encountered during and after the activities. In the weekly analyses, the data collected after each activity was analyzed, and problems regarding argumentation skills development were identified. In this process, the teacher and student diaries, video-recordings, and activity papers were analyzed and compared. This made it possible to see the problems from the teachers' and students' perspectives, and provided confirming information through data variety. These findings became an important source for improving the effectiveness of the process, and for the adjustments to be made in the following stage.

Problem codes regarding argumentation skills development were created during the analysis process. Then, the codes were grouped based on similarities and differences and the problem categories were established. The problem categories which were consistent with the related literature were analysed in terms of meaning and relation. After that, the problems themes were made up. These findings, based on the stages in which they occurred, were grouped under problems encountered during the claim-warrant-evidence development process; 
problems encountered during the counter claim and counter warrant development process; and problems encountered during the rebuttal development process.

\section{Credibility and Validity Studies During Research}

Actions taken in order to ensure the validity and credibility of the research results are as follows:

Data was collected from different sources in the research study, and the process was recorded in order to prevent data loss and long-term interaction ensured. The study group was identified in detail in order to allow transferability. The ways in which research results were achieved, as well as evidence regarding inferences were presented clearly and plainly. The video-recordings, other records in relation to the process, data analyses and interpretations were presented to the review of field experts at a validity meeting conducted after the process. In this way, it was ensured that the researchers were given the opportunity to constantly and critically question and monitor themselves, as well as the process, and that their comments regarding the occurrences or facts they thought they had observed reflected the reality. Throughout the activities the researchers consistently questioned their role in the research process, and whether or not they were exhibiting any bias. The credibility of the research results was ensured by submitting the data set throughout the process to the review of an expert in argumentation skills and qualitative research knowledge. The coding of the expert and that of the researchers were compared, and any codes that created difference of opinion were resolved by discussing them with the expert.

\section{Findings}

\section{The Findings of Stage 1 (Claim-warrant-evidence development)}

The findings in this phase were given under two headings as the findings related to claimwarrant-evidence generation skill development and the findings regarding problems encountered in the claim-warrant-evidence development process. 


\section{The findings related to claim-warrant-evidence generation skill development}

Table 2 shows the argument structures in written documents and verbal argumentation process in the process of the claim-warrant-evidence development and the frequency of students in each classification.

Table 2

Argument Structures and Numerical Data Regarding Claim-WarrantEvidence Generation Skill Development

\begin{tabular}{|c|c|c|c|c|c|c|c|}
\hline \multicolumn{8}{|c|}{ Argument structures and numerical data in written documents } \\
\hline \multirow{3}{*}{ Argument Structures } & \multicolumn{7}{|c|}{ Activity numbers } \\
\hline & A2 & A3 & A4 & A5 & A6 & A7 & A8 \\
\hline & $\mathrm{f}$ & $\mathrm{f}$ & $\mathrm{f}$ & $\mathrm{f}$ & $\mathrm{f}$ & $\mathrm{f}$ & $\mathrm{f}$ \\
\hline Only claim & 22 & 15 & 5 & - & - & - & - \\
\hline Claim + One warrant & 3 & 6 & 13 & 14 & 5 & - & - \\
\hline Claim + More than one warrant & 1 & 3 & 3 & 3 & 5 & 3 & - \\
\hline Claim + Warrant + Evidence & - & 2 & 5 & 9 & 16 & 19 & 19 \\
\hline $\begin{array}{l}\text { More than one claim }+ \text { Warrant }+ \\
\text { Evidence }\end{array}$ & - & - & - & - & - & 4 & 7 \\
\hline Total & 26 & 26 & 26 & 26 & 26 & 26 & 26 \\
\hline \multicolumn{8}{|c|}{ Argument structures and numerical data found in verbal argumentation process } \\
\hline \multirow{3}{*}{ Argument Structures } & \multicolumn{7}{|c|}{ Activity numbers } \\
\hline & A2 & A3 & A4 & A5 & A6 & A7 & A8 \\
\hline & $\mathrm{f}$ & $\mathrm{f}$ & $\mathrm{f}$ & $\mathrm{f}$ & $\mathrm{f}$ & $\mathrm{f}$ & $\mathrm{f}$ \\
\hline Only claim & 16 & 8 & 5 & 2 & - & - & - \\
\hline Claim+ One warrant & 2 & 6 & 10 & 10 & 3 & - & - \\
\hline Claim + More than one warrant & 1 & 3 & 3 & 3 & 5 & 3 & - \\
\hline Claim + Warrant + Evidence & - & 1 & 2 & 3 & 11 & 19 & 17 \\
\hline $\begin{array}{l}\text { More than one claim }+ \text { Warrant }+ \\
\text { Evidence }\end{array}$ & - & - & - & - & - & 4 & 7 \\
\hline Total & 19 & 18 & 20 & 18 & 19 & 26 & 24 \\
\hline
\end{tabular}

When Table 2 was examined, five structures of argument were identified, which became distinct in terms of the type and number of components in the written and verbal argumentation process during the stage of gaining claim-warrant-evidence generation skills. When findings regarding arguments that were comprised only of a claim were analyzed, it was seen that arguments of this structure decreasingly continued throughout the first four activities. It was observed that students who developed arguments of this structure merely asserted a claim in their explanations, and did not include any statements relating to how this opinion could be valid and correct. An argument that exemplifies this situation is as follows: "I think this technology should be used on perfect humans. They should select one or two people from each area of science and use it on them..." (S12) 
On the other hand, it was observed that argument structures that are comprised of claim and a warrant were generated by three students during the written argumentation process in the initial activity, and only by two during the verbal argumentation process. Additionally, an increase was observed in the number of arguments until the fifth activity, and a reduction after that point, coming to an end in the seventh activity. An excerpt from the process of verbal argumentation with this argument structure is as follows: "People should not be given a chance to choose their child's gender. If so, the number of boys will increase in our country and the natural balance will be lost ..." (S11)

When this explanation is examined, we can say that a warrant which supports the claim was presented, the information is structured in a more orderly fashion, and that awareness is taking shape regarding the necessity of a supporting statement.

After that, it was followed that a significant number of students started to use the claim and more than one warrant argument structures earlier than the claim-warrant-evidence argument structures. In this phase, instead of supporting their claims through evidences, they tended to use more than one warrant. This type of arguments structures can be exemplified as below:

\section{"I would have allowed the use of GMO products. Because that would mean more crops would be produced, and everyone would be able to get cheaper food, and agricultural pesticide use would go down, making us less affected by chemicals that are harmful to our health..." (S17)}

The argument structure made up of claim-warrant-evidence was observed to have a slow progress throughout the phase, and was generated by all students in the last two activities. Seven of the students were seen to improve their argument structures in this phase, combining claim-more than one warrants- more than one evidence. Examinations of the data showed that these seven students with better academic achievement demonstrated faster progress in terms of argumentation skills, and produced better quality arguments. At the same time, these examinations revealed that the development process of this skill in the four pupils with lower academic achievement progressed more slowly compared to others. An excerpt from the verbal argumentation process serving as an example of the argumentat structure of claim-multiple warrants-evidence is shown below: 
"Teacher, I think it is necessary for our country to construct HPPs, I mean they must be built. Because there is an ever-growing need for energy, and if they build HPPs, it could be a solution to the energy problem -How? How can you prove what you just said? - I can talk about my research results. As HPPs are renewable energy sources, they work with over $90 \%$ efficiency without fuel expense, and our country has a huge potential for using them. If we take advantage of this potential, it will resolve our energy problem, and minimize our foreign dependency -So what else can you tell us in favor of building HPPs? -They must be built for the purpose of protecting the environment. Because, they are environmentally-friendly; they can be renewed; and they are clean energy sources. Because they do not produce environmentally hazardous waste or greenhouse gas that lead to global warming. The most important evidence is the fact that it has been supported by UNESCO as environmentally friendly..." (S17)

Regarding the findings of the claim-warrant-evidence development, the participants can be said to develop their claim-warrant and evidence generation skills in the implementation phase with socioscientific issues.

\section{The findings regarding problems encountered in the claim-warrant-evidence development process}

Studies were conducted in order to identify and resolve the problems that were experienced during the claim-warrant-evidence development process in the research. Findings concerning the problems identified at this stage were presented in Table 3.

Table 3

The Findings About Problems Related to the Claim-Warrant-Evidence Development Process

\begin{tabular}{|c|c|}
\hline \multirow[b]{2}{*}{$\begin{array}{l}\text { Problems Related to } \\
\text { Claim-Warrant-Evidence } \\
\text { Development }\end{array}$} & $\begin{array}{l}\text { Problems understanding components of argument-warrant-evidence } \\
\text { - Inability to understand the necessity to present supportive information } \\
\text { - Inability to differentiate warrant and evidence } \\
\text { - Inability to decide what information counts as evidence }\end{array}$ \\
\hline & $\begin{array}{l}\text { Connection problems in generating claim-warrant-evidence } \\
\text { - Presenting warrant that does not support claim } \\
\text { - Presenting evidence that does not support claim and warrant } \\
\text { - Presenting claim and warrant for two opinions } \\
\text { - Presenting religious warrants and being unable to support them with } \\
\text { evidence }\end{array}$ \\
\hline
\end{tabular}




\begin{tabular}{ll}
\hline & $\begin{array}{r}\text { Problems with the teacher } \\
\text { - }\end{array}$ \\
Problems about the & $-\quad$ Problems in asking questions \\
teaching-learning process & \\
variables & $\begin{array}{l}\text { Problems with the students } \\
\end{array}$ \\
& - Lack of research skill \\
& Lack of verbal language skills \\
&
\end{tabular}

When Table 3 was examined, the problems experienced in the process of gaining claimwarrant-evidence generation skills were concentrated under two themes.

The problems in claim-warrant-evidence skills development were divided into two categories. Among these, problems in understanding the components of claim-warrantevidence were identified as; inability to understand the necessity to present supportive information, inability to differentiate warrant and evidence, and inability to decide what information can be evidence. The problem of being unable to understand the necessity to present supportive information continued to decrease throughout the first three activities. Students who experienced this problem were observed to have only expressed their claims during the argumentation phase, and not generated supportive warrant and evidence as to why this opinion might be correct. It was established that students present the warrant as evidence, as part of the problem of being unable to differentiate between warrant and evidence. When failing to decide what information could be used as evidence, students were observed to have used statements such as "I carry out experiments as evidence" rather than using scientific data or epitomic information. Under the category of connection problems in argument-warrantevidence generation, the problems of presenting warrants that did not support the claim, presenting evidence that did not support the warrant, presenting claim and warrant for both opinions, presenting religious warrants, and an inability to support statements with evidence were identified. These problems demonstrated that while awareness was formed regarding components of argumentation, there was a failure in establishing the correct connections. Furthermore, it revealed the fact that students were not making statements focused on a particular opinion, and that they presented religious warrants, unable to establish an evidencebased connection. An exemplifying excerpt demonstrating the problem of presenting religious warrants and being unable to support them with evidence is as follows: "I do not want there to be a way to create perfect human beings. Because God creates everyone as He sees fit, and it is a sin anyway. So I don't agree with this opinion..." (S15) 
In order to resolve such problems detected during the process, meetings were conducted with the students along with the teacher. In these meetings, the students were given extra explanations and feedback. New activities were organized to give the students to acquire new experiences. The second theme, problems concerning variables in the education process, can be grouped under two categories. One of these are problems identified in the teacher, and they were established as problems in asking questions, and with confidence andanxiety. As for the problems about questioning, it was observed that especially in the first sessions of the implementation, the teacher forgot asking questions which guided the students to produce the warrant and the evidence such as -Why do you think so? -What is your warrant? -Do you have any evidences? - What are they? In these situations, it was seen that the student gave an explanation. The teacher listened to him/her but did not ask any further questions. Instead, the teacher allowed another student to talk.

Again, in this phase, the teacher was seen to have experienced a lack of confidence and anxiety. Both problems were solved in time as the teacher gained experience. On the other hand, problems detected in the students were identified as lack of research skill, lack of verbal language skills and lack of supportive information.

In cases where the problem in verbal argumentation skills development was experienced, students were observed to have failed to fully express their thoughts, or to have put forth disorganized explanations. When the causes of this problem, which were more often observed in students with lower levels of academic achievement, were examined, insufficient verbal linguistic skills development, nervousness and lack of experience were identified among these causes. Additionally, it was observed that several students were able to generate better arguments in writing, even though they could not do that verbally, which meant that their verbal argumentation skills developed more slowly. The research study also showed that students experienced problems related to insufficient supportive information at the time of argument generation phase. In order to resolve this problem, students were provided with information early on regarding the activity's topic. In this way, students were given the opportunity to acquire knowledge on the topic, and encouraged to do research. 
Consequently, it can be said that various problems were experienced in relation to the education process during the argument-warrant-evidence development phase, and that they were resolved.

\section{The Findings of Stage 2 (Counter Claim-Counter Warrant Development)}

The findings in this phase were given under two headings as "the findings related to counter claim and counter warrant generation skill development" and "the findings regarding problems encountered in the counter claim -counter warrant development process".

\section{The findings related to counter claim and counter warrant generation skill development}

Table 4 shows the argument structures related counter claim and counter warrantin the written documents and verbal argumentation process and the frequency of the students.

Table 4

\section{Argument Structures and Numerical Data Regarding Counter Claim-Counter Warrant} Generation Skill Development

\begin{tabular}{|c|c|c|c|c|c|c|}
\hline \multicolumn{7}{|c|}{ Argument structures found in written documents and the numerical data } \\
\hline \multirow[t]{3}{*}{ Argument Structures } & \multicolumn{6}{|c|}{ Activity numbers } \\
\hline & A10 & A11 & A12 & A13 & A14 & A15 \\
\hline & f & $\mathrm{f}$ & $\mathrm{f}$ & $\mathrm{f}$ & $\mathrm{f}$ & $\mathrm{f}$ \\
\hline Claim-Warrant-Evidence & 21 & 16 & 5 & - & - & - \\
\hline Claim-Warrant-Evidence-Counter Claim & 4 & 6 & 8 & 7 & 4 & - \\
\hline $\begin{array}{l}\text { Claim-Warrant-Evidence-Counter Claim- } \\
\text { Counter Warrant }\end{array}$ & 1 & 3 & 10 & 15 & 16 & 18 \\
\hline $\begin{array}{l}\text { More than one claim-Warrant-Evidence- } \\
\text { Counter Claim- Counter Warrant }\end{array}$ & - & 1 & 3 & 4 & 6 & 8 \\
\hline Total & 26 & 26 & 26 & 26 & 26 & 26 \\
\hline \multicolumn{7}{|c|}{ Argument structures found in the process of verbal argumentation and the numerical data } \\
\hline \multirow[t]{3}{*}{ Argument Structures } & \multicolumn{6}{|c|}{ Activity numbers } \\
\hline & A10 & A11 & A12 & A13 & A14 & A15 \\
\hline & $\mathrm{f}$ & $\mathrm{f}$ & $\mathrm{f}$ & $\mathrm{f}$ & $\mathrm{f}$ & $\mathrm{f}$ \\
\hline Claim-Warrant-Evidence & 19 & 16 & 5 & - & - & - \\
\hline Claim-Warrant-Evidence-Counter Claim & 4 & 6 & 8 & 5 & 4 & - \\
\hline $\begin{array}{l}\text { Claim-Warrant-Evidence-Counter Claim- } \\
\text { Counter Warrant }\end{array}$ & 1 & 3 & 8 & 10 & 12 & 16 \\
\hline $\begin{array}{l}\text { More than one claim-Warrant-Evidence- } \\
\text { Counter Claim- Counter Warrant }\end{array}$ & - & 1 & 3 & 4 & 6 & 8 \\
\hline Total & 24 & 26 & 24 & 19 & 22 & 24 \\
\hline
\end{tabular}

f: frequency of students 
When Table 4 was analyzed, four different argument structures were exhibited in the counter claim and counter warrant development phase. Regarding argument structures with the components of claim-warrant-evidence-counter claim, it was revealed that they were often produced in the first activities and different from the arguments in the first phase, only counter claim component was added into argument structures. An example of a written argument that matches this structure is as follows:

"I think that the use of methyl bromide should be banned. Because methyl bromide is not only risky for the environment, but it also has adverse effects on humans. For example, when it is inhaled in large amounts, it leads to lung and central nervous system diseases... When it comes to its adverse effects on the environment, for example, it thins out the ozone layer, and this has effects on human health, as well as all living species and agriculture... Therefore, I think it should be banned. Those who do not agree with this opinion will think the opposite and say that the use of methyl bromide should not be banned" (S6)

The argument structure comprised of claim-warrant-evidence-counter claim-counter warrant identified at this stage included information regarding the fact that the arguments suggested with the problem were supported with warrants and evidence, and what the counter claim and counter warrant could be in case of a disagreement. A dialog that exemplifies such argument structure is as follows:

\footnotetext{
"-Teacher, I think WPPs should be built -Why? -Because, they are a constant source of energy. They do not need raw materials, they are a domestic energy source, and would meet our energy need to a great extent. Because, WPPs are supposed to have a high potential of $48 M W$ in our country. This shows their importance. -So, what could people who disagree with you argue and what warrants would they give? -They would claim that WPPs should not be built. And their warrant could be that agricultural lands might be harmed" (S11).
}

When these explanations are examined, it is seen that skills to evaluate different points of view other than the one that was argued for were more effectively used.

Another argument structure which was found in this process consisted of more than one claim-warrant-evidence-counter claim- counter warrant. This argument structure was more developed in terms of counter claim and counter warrant components and it was mostly seen in the last activities and showed a faster development with academically high achievers. An example of such arguments is as follows: 
"-I believe it is more important to prevent the spread of microbes in drinking water. Because if not, many people will get sick. Their lives will be in danger. It will also negatively affect the economy. Research studies I found support this. It was determined that around 1 million people around the world died this year due to diseases related to water, and this demonstrates that it is an important problem. Then there are also treatment expenses. Even if these people do not die, lots of money will be spent on treatment expenses as these diseases are rapidly transmitted to others, and this shows that it will greatly damage the economy What could be a counter argument? -People who do not share the same opinion would say that it is more important to minimize the risk of getting cancer from drinking water. As a warrant, they would say that their lives will be in danger, and treatment will be harder and more expensive" (S1).

When findings regarding the development of counter claim and counter warrant were generally assessed, it can be said that as a result of the applications there was a transition from using only the argument structure of claim-warrant-evidence components, to generating arguments ofmore than one claim-warrant-evidence-counter claim- counter warrant, and that the students exhibited different development profiles in this phase.

\section{The findings regarding problems encountered in the counter claim-counter warrant development process}

In comparison to other phases, less problems were encountered in the development of counter claim and counter warrant. The most important problems experienced in this phase were identified as lack of versatile thinking process, lack of effort, andlack of enough knowledge. Among these, the problem of lacking a versatile thinking process was mostly observed in pupils with low academic achievement, and they demonstrated a slower development in counter claim and counter warrant generation skills. As a result of lack of enough knowledge, they produced insufficient warrants. It was observed that they presented comprehensive information supporting claim and warrant but weak information in counter claim and counter warrant. Furthermore; at the beginning of the development process of counter claim and counter warrant, some of the students did not seem to show any efforts to produce counter claims and counter warrants. Instead; they continued to come up with warrant and evidence. This problem was solved in the first two weeks. 
As a solution these problems, the students were re-informed about why important and how to produce counter claim and counter warrant and activities were re-organized to provide more experiences for the students.

\section{The Findings of Stage 3 (Rebuttal development)}

The findings in this phase were given under two headings as "the findings related to rebuttal generation skill development" and "the findings regarding problems encountered in the rebuttal development process".

\section{The findings related to rebuttal generation skill development}

Table 5 presents the argument structures found in the written documents and verbal argumentation process in the phase of rebuttal generation skill development and the frequency of them.

Table 5

Argument Structures and Numerical Data Regarding Rebuttal Generation Skill Development

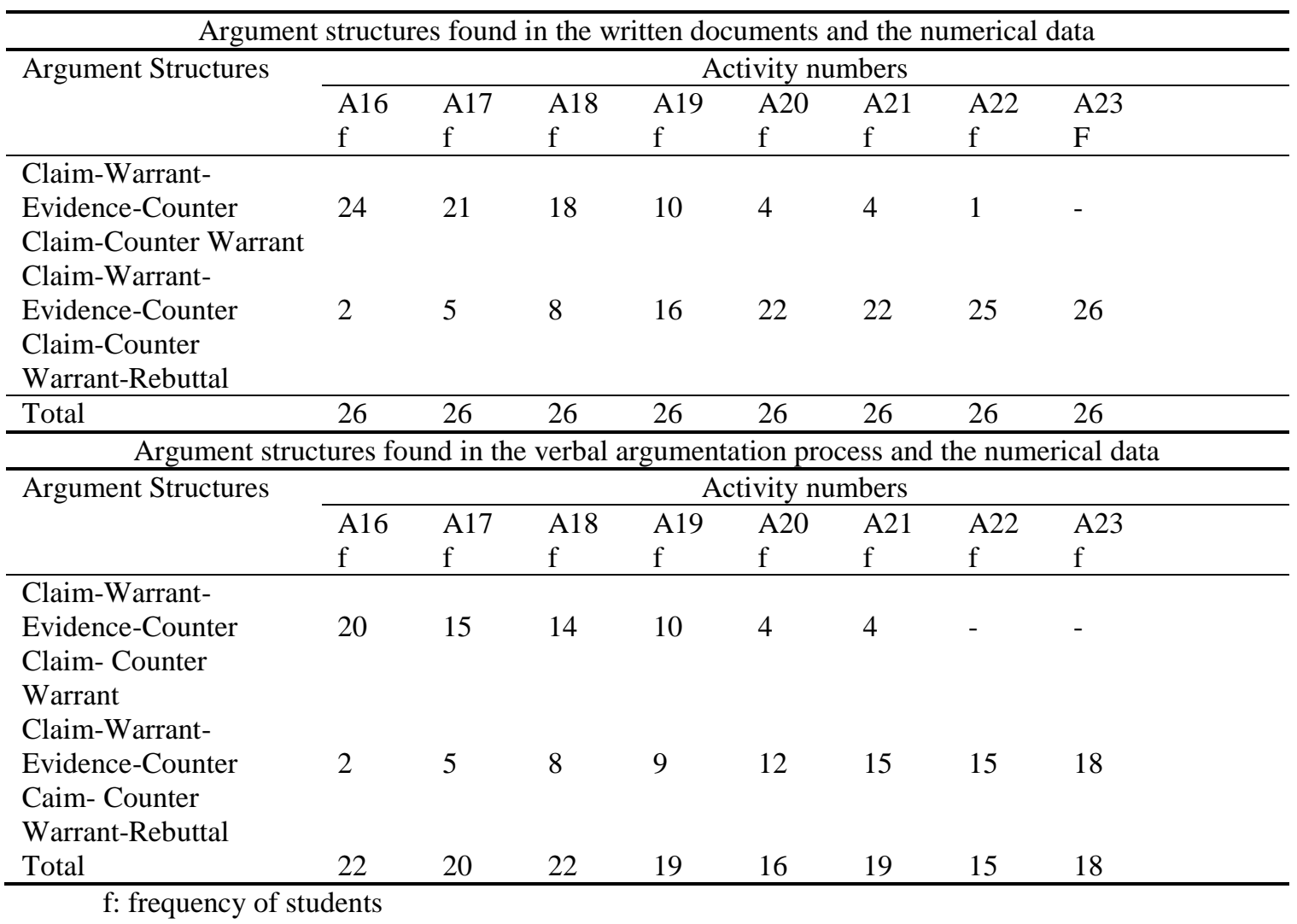


According to Table 5, two argument structures which differed in terms of component types and the number were observed in the process of rebuttal generation skill. Of these, the first argument made up of claim-warrant-evidence-counter claim-counter warrant components was mostly produced during the first activities and in the implementation phase, it continued to decrease. The second argument structure with claim-warrant-evidence-counter claim counter warrant-rebuttal components was not frequent in the first activities but continued to increase in the process. Also, this structure developed slower in the verbal argumentation process than the written argumentation process. In the findings related to the argument structure with claim-warrant-evidence-counter claim-counter warrant -rebuttal components were learned by only two students in the first activity and were developed so slowly. Furthermore, it was seen that the rate of generation rebuttal skill differed among the students. It developed faster with high academic achievers. This skill could not be developed with four lowest academic achievers till the last two activities. An example dialogue related to the use of rebuttal generation skill is as in the following:

"Thermal power plants must be built. Because these plants are imperative for meeting our country's energy need, and in keeping our national income inside the country..."(S9)

“-Teacher, I don't agree with S9. OK, they may make important contributions to meeting energy needs, but they harm the environment. They adversely affect people's right to have a healthy life, and their right to environmental protection...our country has a great potential for clean energy sources, like HPPs and WPPs. Why are they imperative? They could be, if we didn't have other sources of energy, but while we have such opportunities, they are not imperative..." (S11)

These quotations from the verbal argumentation process indicated that the students could develop rebuttals to invalidate each other's perspectives. In this context, it is possible to say that the activities served the purpose of developing rebuttal generation skill.

\section{The findings regarding problems encountered in the rebuttal development process}

Table 6 points out the problems faced in the process of rebuttal generation skill development in the study. 
Table 6.

Findings Related to Problems in the Process of Rebuttal Generation Development

\begin{tabular}{lll}
\hline $\begin{array}{l}\text { Problems about } \\
\text { rebuttal component }\end{array}$ & $\bullet \begin{array}{l}\text { The problem of not being able to understand the rebuttal component } \\
\text { The problem of not being able to conduct a thought process in order } \\
\text { to develop a rebuttal }\end{array}$ \\
\hline $\begin{array}{l}\text { Problems related to } \\
\text { the teacher }\end{array}$ & $\begin{array}{l}\text { Biases and anxiety } \\
\text { Inability to create the appropriate environment for rebuttal } \\
\text { development } \\
\text { The problem of giving feedback in the process of rebuttal producing }\end{array}$ \\
\hline $\begin{array}{l}\text { Problems related to } \\
\text { the students }\end{array}$ & $\begin{array}{l}\text { Biases and anxiety } \\
\text { The problem of not realizing the importance of rebuttal in the } \\
\text { argumentation process }\end{array}$ \\
\hline
\end{tabular}

As seen in Table 6, the problems experienced during the process of the development of rebuttal were categorized under three headings as the ones related to the rebuttal component, related to the teacher and related to the students. Two different problems were identified about the rebuttal component. One of these was the problem of not being able to understand the rebuttalcomponent, which reflected the difficulties students run into in making sense of the concept of rebuttal. Especially in the initial stages of the process, the majority of students experienced difficulties in making sense of the rebuttal component. While the problem of not being able to conduct a thought process in order to develop a rebuttal represented the inability to establish the required context of contemplation in order to generate rebuttal during the argumentation process, that is, the inability to exercise the process of deliberating a counter claim against one's own claim to prove under what conditions such a counter claim would be invalidated. Resolving these problems included conducting interviews with students, and repeatedly providing them with the information on what a rebuttal was, and how they could make use of it. New activities were organized.

Problems related to the teacher were identified as, biases and anxiety, inability to create the appropriate environment for rebuttal development, the problem of giving feedback in the process of rebuttal producing. Such problems were observed in the initial activities. In this sense, the teacher seemed to have biases and anxiety with regards to her competence in the process of rebuttal generation, and failed to offer detailed feedback related to the quality or validity of the rebuttal generated. She also struggled with difficulties about giving answers and explanations to the questions that the students asked about the rebuttal.At the same time, the teacher seems to have preferred to allow studentsto speak at random, rather than making 
encouraging arrangements for students to generate rebuttalby juxtaposing opposing views. In addition to this, the teacher fell short of posing questions to students who disagreed with the generated argument, with regards to why that argument could be invalid. Solution-oriented works were conducted with the teacher before and after the activity in order to be able to address these problems.

Problems regarding biases and anxiety, and the problem of not realizing the importance of rebuttal in the argumentation process as problems related to the students. In terms of bias and anxiety, it was seen that the students had the difficulty of differentiating rebuttal when they first encountered it in comparison to other components.During the implementation process, although some students spent effort to produce other components, they did not show any attempts to produce rebuttal. When they were asked about this, they said that they could not do it even if they worked for it. To resolve these problems, meetings were conducted with the students who experienced this problem, they were encouraged throughout the process, and assistance was provided throughout the process whenever they needed it. Additionally, in this process, some of the students were determined to have difficulties in recognizing the importance of this component, and made statements regarding its redundancy. In this regard, one of the students said the following: “...I'm already presenting a warrant and evidence to support my opinion, don't they prove its accuracy? Why are we doing this, is it really necessary?..."(S13).

As a matter of fact, throughout the process it was observed that students tended to present more warrants and evidences rather than generating rebuttal. To overcome this problem, the students were given extra information and explanation about the importance of the rebuttal. Furthermore, these students were put together with the students who were good at producing rebuttals. In doing so, they were guided to realise that only supporters were not enough in this process.

\section{Discussion, Conclusion and Implications}

The results of the study highlighted that SSI-based implementations developed 8th graders' argumentation skills and the quality of arguments produced in this process changed in a 
positive way. Similar results regarding the success of SSI-based activities in developing argumentation skills were identified in different studies. Lin and Mintezs (2010) carried out a study with 6th graders and investigated the development of argumentation skills in socioscientific issues. The results of their study showed that the students improved their argumentation skills such as their claim, rationale, evidence and counter argument. Maloney and Simon (2006), in their study with children aged 10 and 11, aimed to develop argumentation and decision making skills in the context of socioscientific issues. Four activities were practised in three different schools. At the end of the study, a development was observed in the students' argumentation skills. In another study Atabey and Topçu (2017) in their study, demonstrated that SSI based instruction is an effective approach to improve the middle school students' argumentation quality. In their high school genetics classes, Dawson and Venville (2010) implemented class discussions and writing activities related to socioscientific topics to develop the students' argumentation skills. They observed a development in the students' argumentation skills and they highlighted four important factors in developing argumentation skills: class discussions, the implementation of writing activities, socioscientific issues and student roles. Evren Yapıcıŏlu and Kaptan (2018) studied with science teacher candidates using mixed research method, showed that socioscientific situation-based teaching approach affected positively the development of argumentation skills. Topçu \& Atabey (2017) investigated socioscientific issues based field trips affects on argumentation quality. The results showed that socioscientific issues based field trips developed students' argumentation quality. Zohar and Nemet (2002) investigated dilemmas in human genetics and teaching argumentation skills. They found out that nearly 90 $\%$ of the students were successful in developing arguments and there was an increase with the quality of arguments. When these findings in the related literaure have in general been considered, it can be said that socioscientific issues develop argumentation skills.

On the other hand, the argumentation skill development was also investigated in the related literature in terms of academic achievement. Of these, Zohar and Dori (2003) carried out a study with secondary school students and found out that students at all grades could develop their argumentation skills after they were given training but high achievers exhibited more advanced argumentation skills. While in their studies Lin and Mintzes (2010) showed that there is a close relationship between argumentation skills and academic achievement, and that students with high academic achievement developed a much more advanced argumentation 
skills compared to those with lower levels of academic achievement. Hakyolu (2010) also supported these findings with his research. In his study with students from different levels of academic achievements, Hakyolu revealed that the students with high achievement level were better at both participating in argument situations and producing quality arguments. It can be said that such findings support the conclusion of this study that more successful students show faster development pattern and produce richer argument structures.

More comparisons were found in the relevant literature, such as Puvirajah (2007) who analyzed the validity and quality of arguments and revealed the necessity of having evidence to support claims and establish quality arguments, as well as the importance of acquiring the habit of conducting scientific research in order to do that. According to Levinson (2006), research should be done in order to provide evidence for SSI except science classes. Similarly, Kariper, Akarsu, Slisko, Corona and Radovanovic (2014) draw attention to the importance of scientific research for the development of argumentation. Demircioğlu and Uçar (2014) stated that students develop and defend claims with more scientific explanations after reading scientific articles.In that regard, it is possible to say that this study accurately identified the lack of research skills as a problem within the process, and established the necessity of conducting studies for resolving this problem.

When problems identified in the development of argumentation skills were further assessed within the context of findings in the related literature, Zeidler's (1997) carried out a study about the influential factors on the argumentation process and the reasons of the students' mistakes. Zeidler identified lack of previous experience in producing arguments, the presentation of insufficient evidence, and the effects of fundamental beliefs on arguments as causes of these mistakes. In relation to that, he said that inexperienced students' prejudice, their inability of producing evidence, the effect of beliefs on argumentation process and uncertainty over what constitutes accurate evidence were the leading sources of the mistakes. Johnson (1996) considered the inability to differentiate evidence and warrant to be one of the problems encountered in the process of argumentation. Zeidler, Osborne, Erduran, Simon, \& Monk, (2003) demonstrated that students experienced problems in recognizing the difference between the components of data, warrant and evidence. In their study with the students between 12 and 17 years old, Dawson and Venville (2010) found out that a great majority of the students could not support or justify their claims or could only produce simple warrants, 
could not do reasoning. Martín-Gámez and Erduran (2018) stated that pre-service teachers had problems in understanding arguments. In this context, they indicated that pre-service teachers did not understand the function and the meaning of warrants. Sadler and Donnelly (2006), in their study with high school students, identified that moral thinking and content knowledge were influential factors on the quality of argumentation. According to Evren Yapıcıoğlu and Kaptan (2018), religious judgments and content knowledge are important factors for the decisions on socioscientific issues. Hogan (2002) with secondary students and Zeidler, Walker, Ackett, and Simmons (2002) with high school students showed that beliefs and moral thinking were effective on decision making in SSI. In this context, it can be said that religious and moral explanations are influential of the process of decision making (Simonneaux, 2007). Sadler and Zeidler (2005b) worked on the relationship between content knowledge and argumentation skill and mentioned that content knowledge was effective on the validity of arguments. They added that the students with broad content knowledge were good a reflecting their background on the process of argumentation and the students with narrow content knowledge could not show their content background as evidences. As a matter of fact, according to Kind, Kind, Barmmby and Adamson (2009), there is a significantly meaningful relationship between argumentation and students' existing knowledge. Duschl and Osborne (2002) and Aufschnaiter, Erduran, Osborne and Simon (2008) presented parallel findings, saying that as the students' knowledge level increased, their argumentation skill increased as well. According to various studies about the argumentation skill, it was claimed that the students were not ready to analyse the others' claims and warrants, to structure and support their own arguments (Driver et al. 2000; Jimenez-Aleixandre et al. 2000). When these findings were assessed in a general sense, biases based on lack of experience, inadequacies in generating evidence and warrant, reflection of beliefs and moral contemplation in the argumentation process, the inability to decide what the quality of evidence might be, the inability to differentiate between warrant and evidence, lack of supportive information and in that context of content knowledge, and incompetence in the analysis of counter arguments (counter claim and its warrants) can be considered to be some of the problems encountered in the development of argumentation skills. On this note, problems regarding confidence, concern and bias based on lack of experience, and problems regarding the inability to generate supporting warrant and evidence, inability to support arguments as a result of presenting religious warrants, inability to decide what information can be counted as evidence, inability to differentiate between 
warrant and evidence, and lack of supporting information, all of which were identified within the scope of this research study, are supported by the findings in the relevant literature. On the other hand, the results of this study reveal the existence of problems such as the fact that developing rebuttal generation skills takes a long time, and that the process of generating rebuttal is not fully understood and a context of contemplation cannot be established. The generation of rebuttal is a process that requires a high level of contemplation skills, and is a significantly difficult task for the majority of students (Lin \& Mintzes, 2010). Wu and Tsai (2007) showed that only $38 \%$ of the high school students could produce rebuttals. It is a probable outcome that this process, which requires the use of advanced contemplation skills, and arguments and counter arguments to be considered together prior to generating rebuttal (Kuhn, 1991), so it is a probable result that primary school students show a slower development process.

Furthermore, the teacher was observed to have experienced problems throughout the process in relation to asking questions, lack of confidence, anxiety, and process management. Considering the fact that experience has been a significant factor in resolving problems related to the teaching process, as well as in improving the process management (Byra \& Sherman, 1991; Fernandez \& Ritchic, 1992), and that such problems are automatically resolved throughout the process in parallel with the experiences gained, such problems related to the teacher could be associated with lack of experience regarding argumentation skills education. Similarly, different studies draw attention to the lack of teachers' and preservice teachers' knowledge and skill for teaching argumentation skills. In this context, they emphasize the importance of conducting studies to provide experience for teaching argumentation skill (Martín-Gámez \& Erduran, 2018; McNeil, González - Howard, Katsh Singer \& Loper, 2016; Uçar \& Demiraslan Çevik, 2017). In the light of these results, some suggestions can be given:

The study was conducted with a group of 26 students attending a middle socio-economic class school. In this context, these results obtained from the research are only generalizable for this group of students and therefore limited to its own context. In order to obtain broader results, studies should be done with students from different socio-economic classes and classes grades. 
In this present research, the implementation process was managed by an experienced teacher. It has been known that the year of experience and level of expertise are influential factors in classroom practices. Follow-up studies with teachers having different skills may provide more comprehensive information both for the problems in this process and opportunities to see whether these problems differ or not.

During the implementation process, the teacher encountered problems and the problems were solved. In-service teacher training programmes should be held to equip teachers with knowledge and skills about what kind of managements should be done to improve the students' argumentation skills.

In this research, it was seen that not all students were good at developing argumentation skills at the same pace. As it has been found out that low achievers have been slow in this process, it is clear that they need more experience. Moreover; it is suggested that students should be given feedback about their development, problem-focused meetings should be organized and students should be helped when needed. In addition, it is recommended that achievement level differences among students should be considered and the process should be observed carefully and students should be presented practice opportunities until their argumentation skills developments are complete. 


\section{References}

AAAS (American Association for the Advancement of Science). (1990). Science for all Americans. New York: Oxford University Press.

Akbaş, M., \& Çetin, P.S. (2018). Üstün yetenekli öğrencilerin çeşitli sosyobilimselkonulara ilişkin argümantasyon kalitesinin ve informal düşünme becerisinin incelenmesi. Necatibey Ĕgitim Fakültesi Elektronik Fen ve Matematik Eğitimi Dergisi, 12(1), 399360

Aldağ, H. (2006). Toulmin tartışma modeli. Çukurova Üniversitesi Sosyal Bilimler Enstitüsü Dergisi, 15 (1), 13-34.

Atabey, N., \& Topçu, M. S. (2017). The effects of socioscientific 1ssues based instruction on middle school students' argumentation quality. Journal of Education and Practice, $8(36), 61-71$

Aufschnaiter, C., Erduran, S., Osborne, J., \& Simon, S. (2008). Arguing to learn and learning to argue: Case studies of how students' argumentation relates to their scientific knowledge. Journal of Research in Science Teaching, 45(1), 101-131

Bell, R., \& Lederman, N. (2003). Understanding of the nature of science and decision making on science and technology based issues. Science Education, 87(3), 352-377

Best, J. W., \& Kahn, J. V. (2006). Research in education. (10th ed.). New York: Pearson Education Inc.

Burns, A. (2010). Doing Action Research in Language Teaching: A Guide for Practitioners. New York: Routledge

Byra, M., \& Sherman, M. (1991, April). Preactive and interactive decission of experienced and inexperienced novice teachers. Round Table Presentation at The Annual Meeting of the American Educational Research Association, Chicago, IL.

Candan, R. (2006). Ilköğretim 2. kademe 7. ve 8. sinıfta okutulan vatandaşlık ve insan hakları eğitimi dersinin öğretimi ve öğretiminde karşılaşılan güçlükler (Ardahan örneği. Yayınlanmamış Yüksek Lisans Tezi, Selçuk Üniversitesi, Konya.

Calhoun, E. F. (1993). Action research: three approaches. Educational Leadership, 51(2), 6265. 
Cohen, L., \& Manion, L. (1994). Research methods in education (4th ed.). London: Routledge

Dawson, M. V., \& Venville, G. (2010). Teaching strategies for developing students' argumentation skills about socioscientific 1ssues in high school genetics. Research Science Education, 40(2), 133-148

Dawson, V., \& Carson, K. (2017). Using climate change scenarios to assess high school students' argumentation skills. Research in Science \& Technological Education, $35(1), 1-16$

Demircioğlu, T., ve Uçar, S. (2014). Akkuyu nükleer santrali konusunda üretilen yazılı argümanların incelenmesi. Illkögretim Online, 13(4), 1373-1386

Driver, R., Newton, P., \& Osborne, J. (2000). Establishing the norms of scientific argumentation in classrooms. Science Education, 84(3), 287-312

Duschl, R. A., \& Osborne, J. (2002). Supporting and promoting argumentation discourse in science education. Studies in Science Education, 38, 39-72 https://doi.org/10.1080/03057260208560187

Erduran, S., Ardac, D., \& Yakmaci-Guzel, B. (2006). Promoting argumentation in preservice teacher education in science. Eurasia Journal of Mathematics, Science and Technology Education, 2(2), 1-14

Evren Yapıcığlu, A., \& Kaptan, F. (2018). Sosyobilimsel durum temelli öğretim yaklaşımının argümantasyon becerilerinin gelişimine katkısı: bir karma yöntem araştırması. Ondokuz Mayıs Üniversitesi Eğitim Fakültesi Dergisi, 37(1), 39-61.

Fensham, P. J. (2002). Time to change drivers for scientific literacy. Canadian Journal of Science, Mathematics and Technology Education, 2(1), 9-24

Fernandez, T. F., \& Ritchic, G. R. (1992). Reconstructing the interactive science pedagogy: Experiences of beginning teachers implementing the interactive science pedagogy. Research in Science Education, 22(1), 123-131

Güven, S. (2002). lköğretim 7. ve 8. sinıflarda okutulmakta olan vatandaşlık ve insan hakları dersini veren ögrretmenlerin nitelikleri ve derste karşılaştıkları problemler: erzincan ili örneği. Yayınlanmamış Yüksek Lisans Tezi, Atatürk Üniversitesi, Erzurum.

Hakyolu, H. (2010). Farklı ögrenme seviyelerindeki ögrencilerin fen derslerinde oluşturulan argüman ortamlarındaki performansları. Yayınlanmamış Yüksek Lisans Tezi, Marmara Üniversitesi, İstanbul. 
Hogan, K. (2002). Small groups' ecological reasoning while making an enviromental management decision. Journal of Research in Science Teaching, 39(4), 341-368

Jimenez-Aleixandre, M. P., Rodriguez, A. B., \& Duschl, R. A. (2000). Doing the lesson or doing science: argument in high school genetics. Science Education, 84(6), 757-92

Jimenez-Aleixandre, M. P. \& Erduran, S. (2007). Argumentation in science education: an overview. In S. Erduran \& M.P. Jimenez-Aleixandre (Eds.), Argumentation in Science Education: Perspectives from Classroom-Based Research (pp 3-27). Dordrecht: Springer

Johnson, R. H. (1996). The rise of informal logic. Newport News, VA: Vale Press.

Kariper, İ. A., Akarsu, B., Slisko, J., Corona A., \& Radovanovic, J. (2014). Fen ve teknoloji öğretmenlerinin argümantasyon tabanlı bilim öğrenme becerileri. Erciyes Üniversitesi Fen Bilimleri Enstitüsü Dergisi, 30(3), 174-179

Kelly, G. J., Druker, S., \& Chen, C. (1998). Students' reasoning about electricity: combining performance assessments with argumentation analysis. International Journal of Science Education, 20, 849-872.

Kind, P.M., Kind V., Barmby, P., \& Adamson, H. (2009, 31 August-4 September). Scientific argumentation, epistemic belief and attitude-A quantitative correlational study of 1415-year-old students. Paper presented at 8. European Science Education Research Association (ESERA) Annual Conference, İstanbul, Turkey.

Kıvanç. Ö. (2003). İlköğretim İnsan Hakları Eğitimi Sürecinin Avrupa Konseyi Insan Hakları Ĕ̈itimi Çerçevesinde Öğretmenler Tarafından Dĕ̌erlendirilmesi (Yayımlanmamış Yüksek Lisans Tezi). Çukurova Üniversitesi, Adana.

Kuhn, D. (2010). Teaching and learning science as argument. Science Education, 94(5), 810824.

Kuhn, D. (1991). The skills of argument. New York: Cambridge University Press

Lazarou, D., Sutherland, R., \& Erduran, S. (2016). Argumentation in science education as a systemic activity: An activity-theoretical perspective. International Journal of Educational Research, 79, 150-156.

Levinson, R. (2006). Towards a theoretical framework for teaching controversial socioscientific 1ssues. International Journal of Science Education, 28(11), 1267-1287

Lin, S. S., \& Mintzes, J. J. (2010). Learning argumentation skills through instruction in socioscientific issues: The effect of ability level. International Journal of Science and Mathematics Education, 8(6), 993-1017 
Maloney, J., \& Simon, S. (2006). Mapping children's discussions of evidence in science to assess collaboration and argumentation. International Journal of Science Education, $28(15), 1817-1841$

Martín-Gámez, C., \& Erduran, S. (2018). Understanding argumentation about socio-scientific issues on energy: a quantitative study with primary pre-service teachers in Spain. Research in Science \& Technological Education, 36(4), 463-483

McNeil, K. L., González-Howard, M., Katsh-Singer, R., \& Loper, S. (2016). Pedagogical content knowledge of argumentation: using classroom contexts to assess high-quality PCK rather than pseudoargumentation. Journal of Research in Science Teaching, 53(2), 261-290

Molinatti, G., Girault, Y., \& Hammond, C. (2010). High school students debate the use of embriyonic stem cells: The influence of context on decission-making. International Journal of Science Education, 33(16), 2235-2251

Neuman, W. L. (1991). Social research methods: Qualitative and quantitative approaches. Boston: Allyn and Bacon

Newton, P., Driver, R., \& Osborne, J. (1999). The place of argumentation in pedagogy of school science. International Journal of Science Education, 21 (5), 553-576

Osborne, J., Erduran, S., \& Simon, S. (2004). Enhancing the quality of argumentation in school science. Journal of Research in Science Teaching, 41(10), 994-1020

Osborne, T., Collins, S., Ratclife, M., Miller, R., \& Duschl, R. (2003). What ideas-aboutscience should be taught in school science? A Delphi study of the expert community. Journal of Research in Science Teaching, 40(7), 692-720

Özdem Yilmaz, Y., Cakiroglu, J., Ertepinar, H., \& Erduran, S. (2017). The pedagogy of argumentation in science education: science teachers' instructional practices. International Journal of Science Education, 39(11), 1443-1464.

Öztürk, A. (2017). An investigation of prospective science teachers' socio-scientific argumentation processes in terms of metacognition: A causal-comparative study. Pegem Ĕ̆itim ve Öğretim Dergisi, 7(4), 547-582.

Pine, G. J. (2009). Teacher action research. Boston: Sage.

Pine, G. J. (1981). Collaborative action research: The integration of research and service. Paper presented at the American Association of College Teachers of Education. Detroit. Retrieved from https://eric.ed.gov/?id=ED199221 
Puvirajah, A. (2007). Exploring the Quality and Credibility of Students' Argumentation: Teacher Facilitated Technology Embedded Scientific Inquiry. Unpublished Doctoral Thesis. Wayne State University, USA. Retrieved from ProQuest Dissertations and Theses database. (UMI No. 3289408)

Ratcliffe, M., \& Grace, M. (2003). Science education for citizenship. Maidenhead, UK: Open University Press

Richards, J. C., \& Farrell, T. S. C. (2005). Professional development for language teachers: strategies for teacher learning. New York: Cambridge University Press.

Ritchie, S. M., Tomas, L., \&Tones, M. (2011). Writing stories to enhance scientific literacy. International Journal of Science Education, 33(5), 685-707

Roberts, D.A. (2007). Scientific literacy /Science literacy. In S.K. Abell \& N.G. Lederman (Eds), Handbook of research on science education (pp.729-780). Manway N.J.: Lawrance Erlbaum Associates, Inc., Publishers.

Romero, M. F. G. (2018). Socioscientific argumentation and model-based reasoning: A study on mining exploitation in Colombia. Universitas Psychologica, 17(5), 1-12.

Sadler, T. D., \& Zeidler, D. L. (2005a). Patterns of informal reasoning in the context of socioscientific decision making. Journal of Research in Science Teaching, 42(1), $112-138$.

Sadler, T.D., \& Zeidler, D.L. (2005b). The significance of content knowledge for informal reasoning regarding socioscientific issues: Applying genetics knowledge to genetic engineering issues. Science Education, 89(1), 71-93

Sadler, T.D. (2004). Informal reasoning regarding socioscientific issues: A critical review of research. Journal of Research in Science Teaching, 41(5), 513-536

Sadler, T. D., Chambers, F. W., \& Zeidler, D. L. (2004). Student conceptualizations of the nature of science in response to a socioscientific issue. International Journal of Science Education, 26, 387-409

Sadler, T.D., \& Donnelly, L.A. (2006). Socioscientific argumentation the effects of content knowledge and morality. International Journal of Science Education, 28(12), 14631488

Smulyan, L. (1983, April). Action research on change in schools: a collaborative project. Paper presented at the Annual Meeting of the American Educational Research Association. Retrieved from https://files.eric.ed.gov/fulltext/ED235192.pdf 
Sandoval, W.A., \& Millwood, K.A. (2008). What can argumentation tell us about epistemology? In S. Erduran\& M.P. Jimenez-Aleixandre (Eds), Argumentation in Science Education: Perspectives from classroom-based research (68-85). Dordrecht Nerherlands: Springer Press

Sandoval, W. A., \& Millwood, K. A. (2005). The quality of students' use of evidence in written scientific explanations. Cognition and Instruction, 23(1), 23-55. https://doi.org/10.1207/s1532690xci2301_2

Simon, S., Erduran, S., \& Osborne, J. (2006). Learning to teach argumentation: research and development in the science classroom. International Journal of Science Education, 28(2-3), 235-260

Simonneaux, L. (2007). Argumentation in socioscientific contexts. In S. Erduran \& M.P. Jimenez-Aleixndre (Eds), Argumentation in science education: Perspectives from classroom based research (179-199). Dordrecht, The Netherlands: Springer

Sürmeli, H. (2010). Üniversite öğrencilerinin biyoteknoloji ve genetik mühendisliği çalışmaları ile ilgili tutum, bilgi ve biyoetik görüşlerinin değerlendirilmesi. Yayınlanmamış doktora tezi, Marmara Üniversitesi, İstanbul.

Topcu, M.S., Sadler, T.D., Yilmaz-Tuzun, Y. O. (2010). Preservice science teachers' informal reasoning about socioscientific 1ssues: The influence of 1ssues context. International Journal of Science Education, 32(18), 2475-2495

Topçu, M. S. \& Atabey, N. (2017). Sosyobilimsel konu içerikli alan gezilerinin ilköğretim öğrencilerinin argümantasyon nitelikleri üzerine etkisi. Bartın Üniversitesi Ĕgitim Fakültesi Dergisi, 6(1), 68-84.

Toulmin, S. (1958). The uses of argument. Cambridge: Cambridge University Press

Tsai, C.Y. (2017). The effect of online argumentation of socio-scientific issues on students' scientific competencies and sustainability attitudes. Computers \& Education, 116, 14 27.

Uçar, B. \& Demiraslan Çevik, Y. (2017, Mayıs). Öğretmen ĕgitiminde teknoloji destekli argümantasyon eğitimi. 11. Uluslararası Bilgisayar ve Öğretim Teknolojileri Sempozyumu (ICITS), Malatya.

Wu, Y-T., \& Tsai, C-C. (2007). High school students' informal reasoning on a socioscientific issue: Qualitative and quantitative analyses. International Journal of Science Education, 29(9), 1163-1187 
Vula, E. \& Saqipi, B. (2015). Developing action research for developing teachers in Kosovo. Turkish Online Journal of Qualitative Inquiry (TOJQI), 6(4), 1-21

Yan, X., \& Erduran, S. (2008). Arguing online: case studies of pre-service science teachers' perceptions of online tools in supporting the learning of arguments. Journal of Turkish Science Education, 5(3), 2-3

Yerrick, R. K. (2000). Lower track science students' argumentation and open inquiry instruction. Journal of Research in Science Teaching, 37(8), 807-838

Yiğittir, S. (2003). İlköğretim 7. Sınıf vatandaşlık ve insan hakları eğitimi dersi özel amaçlarının gerçekleşebilirlik düzeyi. Yüksek lisans Tezi, Gazi Üniversitesi, Ankara.

Yore, L.D., Florence, M. K., Pearson, T. W., \& Weaver, A. J. (2006).Written discourse in scientific communities: A conversation with two scientists about their views of science, use of language, role of writing in doing science, and compatibility between their epistemic views and language. International Journal of Science Education, 28(23), 109-141

Zeidler, D. L. (1997). The central role of fallacious thinking in science education. Science Education, 81(4), 483- 496.

Zeidler, D. L., Osborne, J., Erduran, S., Simon, S., \& Monk, M. (2003). The role of argument and fallacies during discourse about socioscientific issues. In D. L. Zeidler (Ed.), The role of moral reasoning on socioscientific issues and discourse in science education. Dordrecht: Kluwer Academic Press.

Zeidler, D. L., \& Nichols, B. H. (2009). Socioscientific 1ssues; Theory and practice. Journal of Elementary Science Education, 21(2), 49-58

Zeidler, D.L., Walker, K.A., Ackett, W. A. \& Simmons, .M. L.(2002). Tagled up in view: Beliefs in the nature of science and responses to socioscientific dilemmas. Science Education, 86(3), 343-367

Zohar, A., \& Dori, Y. J. (2003). Higher order thinking skills and lowachieving students: Are they mutually exclusive? The Journal of the Learning Sciences, 12(2), 145-182.

Zohar, A., \& Nemet, F. (2002). Fostering students' knowledge and argumentation skills through dilemmas in human genetics. Journal of Research in Science Teaching, 39(1), $35-62$ 